\title{
PERFORATION OF INFERIOR ALVEOLAR NERVE BY MAXILLARY ARTERY
}

\author{
Prakash Billakanti Babu, Ramachandra Bhat K, Vanishree S Nayak \\ Kasturba Medical College, Manipal University, Manipal, Karnataka, India
}

\begin{abstract}
RESUMEN
La fosa infratemporal es un área anatómica clínicamente importante para la administración de agentes anestésicos locales en odontología y cirugía maxilofacial. Fueron estudiadas variaciones en la anatomía del nervio alveolar inferior y la arteria maxilar en la disección infratemporal. Durante la disección rutinaria de la cabeza en el cadáver de un varón adulto, fue observada una variación excepcional en el origen del nervio alveolar inferior y su relación con las estructuras circundantes. El nervio alveolar inferior se originaba en el nervio mandibular por dos raíces y la primera parte de la arteria maxilar estaba incorporada entre ambas. El origen embriológico de esta variación y sus implicaciones clínicas es debatido. Dado que la arteria maxilar transcurría entre las dos raíces de nervio alveolar inferior, y el nervio estaba fijado entre el foramen oval $y$ el foramen mandibular, el atrapamiento vásculo-nervioso pudo causar entumecimiento o dolor de cabeza e interferir con la inyección de anestésicos locales en la fosa infratemporal. Variaciones anatómicas en esta región deben ser tenidas en cuenta, especialmente en casos de tratamiento fallido de neuralgia del trigémino.
\end{abstract}

Palabras clave: Fossa Infratemporal; nervio alveolar Inferior; variación; anatomía aplicada.

\begin{abstract}
Infratemporal fossa is clinically important anatomical area for the delivery of local anesthetic agents in dentistry and maxillofacial surgery. Variations in the anatomy of the inferior alveolar nerve and maxillary artery were studied in infratemporal dissection. During routine dissection of the head in an adult male cadaver an unusual variation in the origin of the inferior alveolar nerve and its relationship with the surrounding structures was observed. The
\end{abstract}

inferior alveolar nerve originated from the mandibular nerve by two roots and the first part of the maxillary artery was incorporated between them. An embryologic origin of this variation and its clinical implications is discussed. Because the maxillary artery runs between the two roots of the inferior alveolar nerve, and the nerve was fixed between the foramen ovale and mandibular foramen, neurovascular entrapment may cause pain numbness or headache and may interfere with the injection of local anesthetics into the infratemporal fossa. Anatomical variations in this region should be kept in mind, particularly in cases of failed treatment of trigeminal neuralgia.

Key words: Infratemporal fossa; Inferior alveolar nerve; Variation; Applied anatomy

\section{INTRODUCTION}

The infratemporal fossa (ITF) lies deep to the ramus of mandible. The ITF contains some of the muscles of mastication, the maxillary artery (MA) and its branches, maxillary vein and its tributaries, and the mandibular nerve (MN) with its branches (DuBrul, 1980; Grant and Sauerland,

\footnotetext{
* Correspondence to: Dr. Prakash Billakanti Babu, Associate Professor, Anatomy Department, Kasturba Medical College, Manipal University, Manipal, Karnataka-576104, India. billakantibabu@yahoo.co.in
}

Received: 6 July, 2011. Revised: 9 August, 2011. Accepted: 30 October, 2011. 


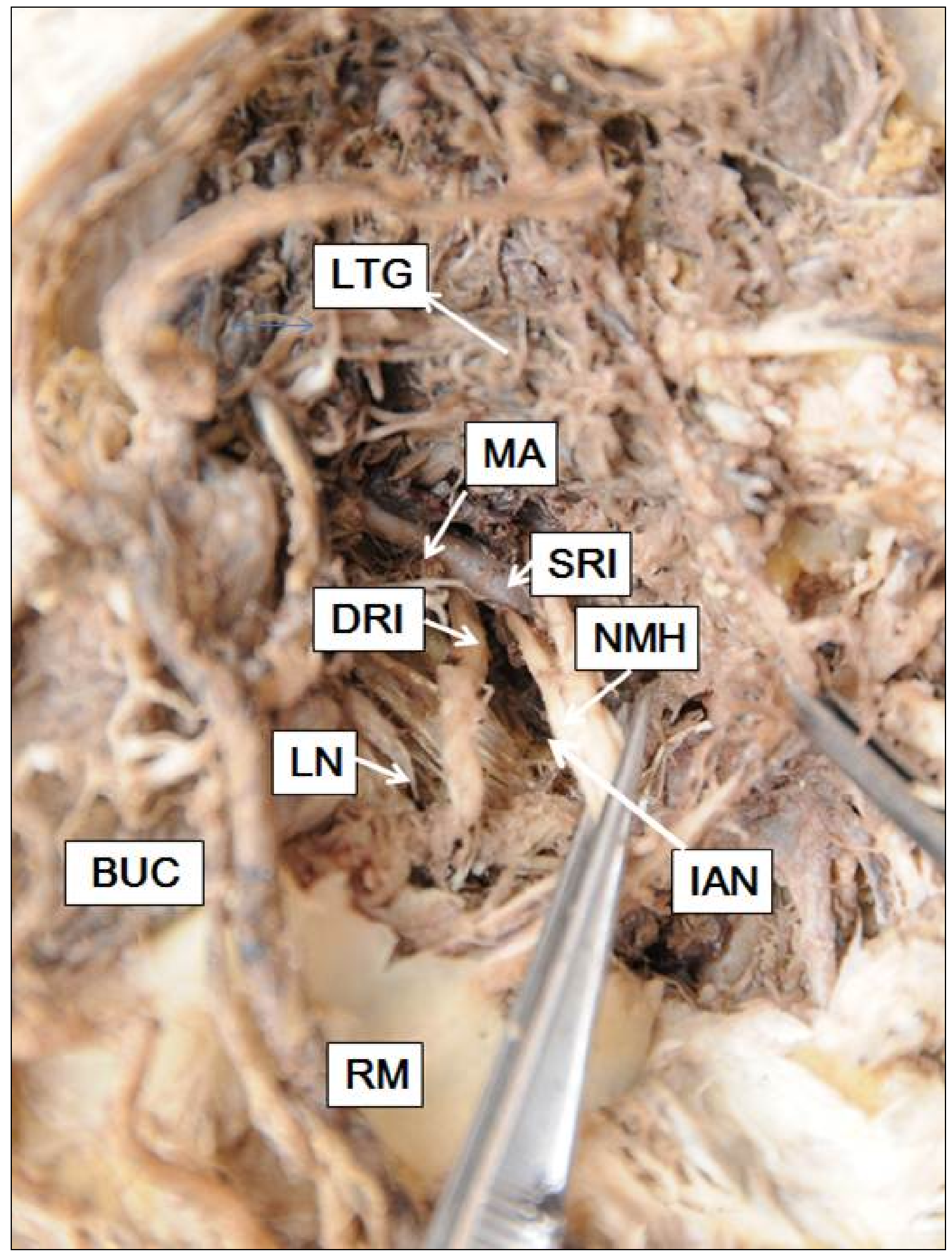

Figure 1: Photograph of the part of dissected left ITF showing: MA: Maxillary artery; IAN: Inferior alveolar nerve; NMH: Nerve to mylohyoid; SRI: Superficial root of IAN; DRI: Deep root of IAN; LN: Lingual nerve and RM: Ramus of mandible; LPt: Lateral pterygoid muscle; BUC: Buccinator muscle 
1984). The MA is the larger terminal branch of the external carotid artery, arises behind the neck of the mandible, and is embedded at first within the parotid gland. It then crosses the ITF to enter the pterygopalatine fossa (PPF) through the pterygomaxillary fissure. The artery is widely distributed through its branches to the mandible, maxilla, teeth, and muscles of mastication, palate, nose and cerebral duramater. The lateral pterygoid muscle divides the MA into three parts first, second and third. Studies by Standring et al (2008), report that the second part of the MA passes either superficial or deep to the lower head of lateral pterygoid muscle.

Mandibular nerve (MN), the largest division of the trigeminal nerve, is a mixed nerve that passes through the foramen ovale (FO) to enter the ITF and lies deep to the lateral pterygoid muscle. The inferior alveolar nerve (IAN) is a branch of the posterior division of the mandibular nerve descends behind the lateral pterygoid muscle. At the lower border of the muscle, the nerve passes between sphenomandibular ligament and ramus of mandible, and enters the mandibular canal through the mandibular foramen. In the mandibular canal it runs downwards and forwards, generally below the apices of the teeth until it is below the first and second premolars where it divides into the terminal incisive and mental branches as reported by Standring et al (2008).

The ITF is clinically important anatomical area for the delivery of local anesthesia in dentistry and maxillofacial surgery (Racz and Maros, 1981). Several primary neoplasms arise in the ITF. The most common of these are neuromas of the lower cranial nerves and glomus jugulare of the vagus nerve (Ballenger and Snow, 1996; Bailey and Calhoun, 1998). Tumors of the salivary glands may spread by perineural metastasis in this region and this route of spread is often overlooked during surgery as reported by Dodd et al (1970). In these cases the maxillary artery (MA) and the branches of the mandibular nerve (MN) may be involved; even the bony foramina and fissures may be occluded. Minimal information is available about the variations of the $\mathrm{MN}$ origin and its relation with the MA in this region. The detailed anatomy of the neurovascular variations of the ITF is important to neurosurgeons, otorhinolaryngologists, dentists, radiologists, and pathologists for prevention of complications during surgical procedures. It is possible to achieve profound regional anesthesia by depositing local anesthetic solution adjacent to the branches of mandibular nerve that are within the ITF. The inferior alveolar nerve block (IANB) can be achieved either transorally or by the external route through the skin of the face as reported by Standring et al (2008). The ITF is difficult to approach for both anatomists and surgeons. Therefore, knowledge of normal variable anatomy is prerequisite for surgical approaches in this area (Bailey and Calhoun, 1998). In the present study we emphasize the relation between the IAN and the first part of the $\mathrm{MA}$ reporting its clinical importance.

\section{CASE REPORT}

During routine dissection of the ITF in an adult male cadaver in the Department of Anatomy, KMC Manipal we found a variation in the anatomy of the IAN on the left side of Head. ITF was dissected according the instructions described in Cunningham's Manual of practical anatomy. After performing osteotomy of zygomatic arch and downward displacement of the masseter muscle, the ramus of the mandible and lower part of temporalis muscle were exposed. Superficial structures of the ITF were exposed after cutting and displacing the coronoid process with the temporalis muscle. Mandibular ramus osteotomy exposed the lateral pterygoid muscle and neurovascular bundle deep to it. After careful dissection of the lateral pterygoid muscle, the MA and the $\mathrm{MN}$ and its branches were identified, freed from the surrounding tissues. Topographical relations of MA and the MN in the ITF were studied. IAN was noted originating from the posterior division of the MN by two distinct long roots, which later joined to form a single trunk. According to their positions, these roots were identified as deep (DRI) and superficial (SRI) (Fig. 1). The nerve to mylohyoid (NM) took origin from the deep root before the roots joined to form the trunk, which coursed deep to the inferior alveolar vessels. The first part of the MA was noted passing through the loop formed by the two roots of the IAN (Fig. 1). The lingual nerve (LN) did not show any communication with the IAN. No abnormality was seen in the branching pattern of the MA. On the right side, IAN did not show any roots and its origin from the MN was normal.

\section{DISCUSSION}

The maxillary artery is the largest terminal branch of the external carotid artery (ECA) arises behind the neck of the mandible within the substance of the parotid gland. It passes horizontally and 
forwards between neck of mandible and sphenomandibular ligament where it lies parallel and little below the auriculotemporal nerve (ATN). It next crosses the IAN, LN and runs along the lower border of lateral pterygoid. Standring et al (2008) reported that second part of MA ascends obliquely forwards medial to temporalis and in $60 \%$ of cases is superficial to lower head of lateral pterygoid. When it runs deep to lateral pterygoid it lies between it and branches of MN. Maxillary artery has been found to divide into superficial and deep branches and later uniting to form a loop. The entire loop was superficial to the branches of the mandibular nerve as reported by Claire et al (2011).

In the present study a variation in the origin of IAN is described where, instead of forming a single trunk, it had two long roots without any communication with other $\mathrm{MN}$ branches. There are few reports by Balcioglu et al (2010) about the variation in the relations between MA and MN. The anatomical findings of two closely related cases were reported previously where the MA pierced the IAN trunk after its origin from the MN (Ortug and Moriggl 1991). Roy et al (2002) reported a single case out of 80 ITF dissected, where the MA passed through the IAN. In the present case, the first part of MA passed through the IAN, splitting the nerve into superficial and deep divisions, which rejoined below the MA. The incidence of the MA piercing the IAN and passing lateral to $L N$, but medial to buccal nerve (BN), without any other important finding has been reported from as high as $5.4 \%$ in Caucasians to as low as $0.3 \%$ in Asian populations (Adachi, 1928; Thomson, 1891). Khan et al (2010) reported maxillary artery passed through the inferior alveolar nerve, splitting it into superficial and deep divisions in 3 of the 50 ITF fossas dissected. The first and second parts of the MA usually passed through the lateral aspect of lateral pterygoid muscle, with the inferior alveolar nerve, lingual nerve and buccal nerve on the medial side of the maxillary artery as reported by Kim et al (2010). There are also reports by Pretterklieber et al (1991) of unilateral variations of the IAN in the following forms: the MA, in addition to piercing the IAN, pierced $L N$ and located deep to BN; the MA pierced only the IAN but passed deep to both the $\mathrm{LN}$ and $\mathrm{BN}$; and the IAN formed a common trunk with the LN, which was pierced by the MA and ran deep to the BN. Studies by Pretterklieber et al (1991) also showed even anastomosis between IAN and LN. In all reported variations, the IAN originated from the $M N$, which was pierced by the MA, a finding quite different from the observations of this report where the initial part of the IAN trunk was formed by two long roots. This type of variation in the origin of the IAN by roots and MA passing between, observed in the present case probably occurs during the earlier part of the embryonic development when the neural crest cells in the cephalic region migrate through the mesoderm of first pharyngeal arch. In the embryo, MN branches pass through the vascular network formed by the MA. Multiple cell-matrix interactions are required for the prescribed pattern of neural crest cell migration in the cranial region (Bronner-Fraser, 1993). As the IAN is a mixed nerve it is possible that the sensory and motor fibers are guided differently and take different pathways for migration. When the motor component (nerve to mylohyoid) leaves for its final destination, the sensory fibers reunite, thereby forming two roots with the NM originating from the deep root of the IAN. These findings indicate that the presence of a double root of the IAN must be considered not only from a clinical application standpoint but also from the aspects of ontogenesis.

Blood supply to the region of the $\mathrm{TN}$ varies at different stages of development. The hemodynamic balance between the developing mandibular and meningeal blood vessels plays a major role in shaping the MA course in the ITF. A vascular network in the pterygoid mass of myoblasts contributes to the formation of the MA in the human embryo (Biermann, 1943; Hogg et al, 1972). The stapedial artery, which is carried distally with the developing $\mathrm{MN}$, feeds the network first and the capillaries pass between the MN fibers. The ECA later joins the vascular plexus. Eventually the vascular plexus disappears to give rise to the adult arterial pattern of the MA in the ITF. In man, the MA usually passes lateral to the $\mathrm{MN}$ branches, although in the present case the artery passed, in part through the IAN. In the embryo, the MN branches pass through a vascular network formed by the MA. Later, either the superficial or deep part of the arterial network disappears; the remaining structures pass superficial or deep to the MN branches in the ITF. The endothelial cells and the myoblasts that form the capillary network are in a dynamic state responding to the need for vascularity. It is possible that the hemodynamic factors under the influence of the pterygoid muscle interact with the developing artery resulting in the individual course of the MA. It appears that some of the capillaries that passed through the branches of the $\mathrm{MN}$ persisted, leading to the MA formation, which passed between two roots of the IAN in the present case. Asymmetry of masticatory system function is well documented in the literature. This may be the 
result of the asymmetrical position of the capillary network that develops into the MA. During surgery in the ITF for the treatment of glomus tumor, petrous apex cholesteatoma, chondroma, lower cranial nerve neuroma and nasopharyngeal cancer, this type of anatomical relationship of the MA with the MN must be considered. Vascular compression of the sensory fibers of the IAN by the pulsating MA may give rise to neuralgia without any neurological deficit. Calvin et al (1977) also reported likewise, there is a possibility of altered sensibility of the mandibular gingival mucosa. The IAN, which is fixed in its course between FO and the mandibular foramen, has to cross the lateral lamina of the pterygoid process or the pterygospinous ligament. With contraction of the lateral pterygoid muscle, the nerve can be entrapped between the bone and the muscle. This tension, combined with the compression by arterial pulsation, may result in pain in the region supplied by the nerve and produce symptoms of mandibular neuralgia as reported by Krampotic-Nemanic et al. (1999). In cases of facial pain or "numb chin syndrome" even if there are no clinical findings of trigeminal neuropathy, the described anatomical variation should be considered. For IAN neurectomy or nerve grafting for repair of the IAN after mandibular resection, the described IAN variation may be observed. Because mandibular nerve block (MNB) and percutaneous electrocoagulation of the $\mathrm{MN}$ are performed for treatment of neuralgic pain through an ITF approach, special caution should be taken in advancing the needle beneath the FO.

Neurovascular variations in the ITF are rare These variations may cause numbness, regional pain or headache. Both surgeons and dentists should always be suspicious of sings of neurovascular compression in the ITF. It has been established that IAN and LN can be pierced during an IANB and the probability of such happening is increased if there is a variation, either in the course of MA or the MN branches, particular that is reported in this study. Clinicians must be aware of such variations if they are injecting local anesthetic into the IAN area. As reported by Roy et al (2002) vascular anomalies in common surgical sites tend to increase the likelihood of damage during procedures, so knowledge of the anatomical variations in this region is not only important for adequate anesthesia but also for the success of dental, oncological and reconstructive operations. This type of variation gives insight into the embryologic origin of neural structures and is potentially important in surgical and dental procedures.

\section{REFERENCES}

Adachi B, Hasebe K. 1928. Das Arteriensystem der Japaner. Kyobo, Maruzen, Kaiserlich Japanischen Universitat zu Kyoto,V.1: 85-92.

Anil A, Turgut HB, Peker $T$, Pelin C. 2000.Variations of the branches of the external carotid artery. Gazi Med J 11: 81-83.

Bailey BJ, Calhoun KH. 1998. Head and Neck Surgery-Otolaryngology. 2nd Ed. Philadelphia: Lippincott-Raven, 683-706.

Ballenger JJ, Snow JB. 1996. Otorhinolaryngology: Head and Neck Surgery. Baltimore: Williams and Wilkins, 249-268.

Balcioglu HA, Kilic C, Varol A, Ozan H, Kocabiyik $N$, Yildirim M. 2010. A Morphometric Study of the Maxillary Artery and Lingula in Relation to Mandibular Ramus Osteotomies and TMJ Surgery. Eur J Dent. 4: 166-70.

Biermann H. 1943. Die chirurgische Bedeutung der Lagevariationen der Arteria maxillaris. Anat Anz 94: 289-309.

Bronner-Fraser M. 1993.Environmental influences on neural crest cell migration. J Neurobiol 24: 233-247.

Calvin WH, Loeser JD, Howe JF. 1977.A neurophysiological theory for the pain mechanism of tic douloureux. Pain 3: 147154.

Claire PG, Gibbs K, Hwang SH, Hill RV. 2011. Divided and reunited maxillary artery: developmental and clinical considerations. Anat Sci Int. April: 1-5.

Dodd GD, Dolan PA, Ballantyne AJ, Ibanez ML, Chau $P$. 1970.The dissemination of tumors of the head and neck via the cranial nerves. Radiol Clin North America 8: 445-461.

DuBrul EL. 1980.Sicher's Oral anatomy. $7^{\text {th }} \mathrm{Ed}$. St. Louis: Mosby.407-414.

Goss CM. 1959.Peripheral nervous system. In: Gray's Anatomy of the Human body. $27^{\text {th }} \mathrm{Ed}$. Philadelphia: Lea and Febiger. 972-973.

Grant JC, Sauerland EK. 1984.Grant's dissector. $9^{\text {th }}$ Ed. Baltimore: Williams and Wilkins.153155.

Hogg ID, Stephens CB, Arnold GE. 1972. Theoretical anomalies of the stapedial artery. Ann Otol Rhinol Laryngol 81: 860-870.

Hollinshead WH. 1968. Anatomy for Surgeons.Vol.1.Head and Neck. New York: Harper and Row. 409.

Khan MM, Darwish HH, Zaher WA. 2010. Perforation of the inferior alveolar nerve by the maxillary artery: An anatomical study. $\mathrm{Br} J$ Oral Maxillofacial Surg.48: 645-7.

Kim JK, Cho JH, Lee YJ, Kim CH, Bae JH, Lee JG, Yoon JH. 2010. Arch Otolaryngol Head Neck Surg. 136: 813-18. 
Krmpotic-Nemanic J,Vinter I, Hat J,Jalsovec D. 1999.Mandibular neuralgia due to anatomical variations. Eur Arch Otorhinolaryngol 256: 205-208.

Lauber $H$. 1901.Ueber einige Varietaten im verlaufe der arteria maxillaris interna. Anat Anaz 19: 444-448.

Lurje A. 1947.On the topographical anatomy of the internal maxillary artery.Acta Anatomica 2: $219-231$.

Ortug G, Moriggl B. 1991.Studies about the topography of the maxillary artery within the infratemporal fossa. Anat Anz 172: 197-202.

Pretterklieber ML, Skopakoff C, Mayr $R$. 1991.The human maxillary artery reinvestigated. I. Topographical relations in the infratemporal fossa. Acta Anatomica.142: 281-287.

Racz, VL, Maros T. 1981.The anatomic variants of the lingual nerve in human. Anat Anz 149: $64-71$.

Roy TS, Sarkar AK, Panicker HK. 2002.Variation in the origin of the inferior alveolar nerve. Clin.Anat.15: 143-147.

Standring $S$, Johnson $D$, Collins $P$, Mahadevan V. 2008. Gray's Anatomy, 40th edition, Churchill Livingstone, London, 446-447.

Thomson A. 1891.Report of the committee of collective investigation of the Anatomical Society of Great Britain and Ireland for the year.1889-90. J Anat 25: $89-101$. 